\title{
Time-Kill Kinetic Effect of Sodium Citrate, Sodium Nitrite and Cinnamaldehyde Against Biofilm Forming Escherichia coli 0157:H7
}

\author{
Jauro Hadiza Abubakar ${ }^{1}$, Iliyasu Mahmud Yerima ${ }^{2}$, Bashir Ismail Olawale ${ }^{2}$, \\ Abdulrahman Ahmad ${ }^{2}$, Musa Usman ${ }^{2}$, Ahmed Faruk Umar ${ }^{2}$ \\ ${ }^{1}$ Gombe State University \\ P. M. B 127, Tudun Wada Gombe, Gombe State, Nigeria \\ ${ }^{2}$ Abubakar Tafawa Balewa University \\ Tafawa Balewa Way, P. M. B. 0248, Bauchi, 740272, Nigeria
}

DOI: $10.22178 /$ pos.77-1

LCC Subject Category: QH1-278.5

Received 20.11.2021

Accepted 28.12.2021

Published online 31.12.2021

Corresponding Author:

Jauro Hadiza Abubakar

hahadiza@gmail.com

(c) 2021 The Authors. This article

is licensed under a Creative

Commons Attribution 4.0

License @) (1)

\begin{abstract}
Food safety is a significant concern of every sector of the food industry. Survival of Escherichia coli 0157:H7 with biofilm-forming potential in commercial food premises is a possible danger to consumers' health, especially in societies where most of the population depend on it for their daily meals. Preservation of fresh food quality being of utmost importance, new innovative means of inhibiting pathogenic microorganisms in foods are being evaluated to be effective at destroying microorganisms and preserving the physical and organoleptic properties. This study aimed to inhibit biofilm formation of Escherichia coli 0157:H7 by food additives; sodium citrate, sodium nitrite and cinnamaldehyde. The isolate obtained was subjected to Gram's staining and various biochemical identifications and later confirmed by the latex agglutination test. The Escherichia coli 0157:H7 was further subjected to a biofilm formation potential test on Congo red media. Antimicrobial susceptibility testing was conducted to obtain the susceptibility/resistance pattern of the isolate to the food additives. The MIC, MBC and time-kill kinetics effect was determined following CLSI 2017 guideline. The highest growth inhibition zone of $31 \mathrm{~mm}$ was exhibited by cinnamaldehyde, followed by sodium nitrite with $26 \mathrm{~mm}$ and sodium citrate with $13 \mathrm{~mm}$. The MIC was determined to be $2.5 \mathrm{mg} / \mathrm{ml}$ for sodium citrate, $0.25 \mathrm{mg} / \mathrm{ml}$ for sodium nitrite and $0.125 \mu \mathrm{l} / \mathrm{ml}$ for cinnamaldehyde. Sodium citrate was found to be bacteriostatic between $6-8$ hrs with $72.9 \%$ reduction, sodium nitrite and cinnamaldehyde exhibit both bacteriostatic and bactericidal effects between 2-24 hrs with percentage inhibition of $65-90 \%$ and $63-100 \%$, respectively. This study showed that sodium citrate, sodium nitrite and cinnamaldehyde exerted strong antimicrobial properties indicating their potential as suitable preservatives.
\end{abstract}

Keywords: food additives; inhibitory effect; time-kill kinetics; biofilm-forming Escherichia coli 0157:H7.

\section{INTRODUCTION}

Food safety is a significant concern of every sector of the food industry. Survival of Escherichia coli 0157:H7 with biofilm-forming potential in commercial food premises is a possible danger to consumers' health, especially in societies where most of the population depend on it for their daily meals. The development of biofilms by the food-borne pathogens attached to surfaces in the food processing environments results in the deterioration of products, persistence of pathogenic bacteria and transmission of food-associated dis- eases [1]. In addition, bacteria in biofilms are more resistant to antimicrobials than their planktonic counterparts, making their elimination from food and the food processing facilities a significant challenge. Therefore, their presence creates excellent and urgent concern for the current food industries (small- and large-scale industries) and public health [2]. Food processing aims to provide safe products with good organoleptic characteristics. This is achieved by using a diverse range of food additives or preservatives to improve and maintain the food quality (nutritional value, texture, safety, taste and appear- 
ance) and safety, thus extending the shelf life of food products. Therefore, eliminating biofilms or minimization of biofilms formed by food-borne pathogens using food additives is essential for consumers to provide safe and suitable quality products. This, in turn, justifies the need for this study. Preservation of fresh food quality being of utmost importance, new innovative means of inhibiting pathogenic microorganisms in foods are being evaluated to be effective at destroying microorganisms and preserving the physical and organoleptic properties.

\section{MATERIALS AND METHODS}

The bacterial isolate (Escherichia coli 0157:H7) was confirmed through Gram's staining and various biochemical identifications and later confirmed by the latex agglutination test (Plate 1) [3].

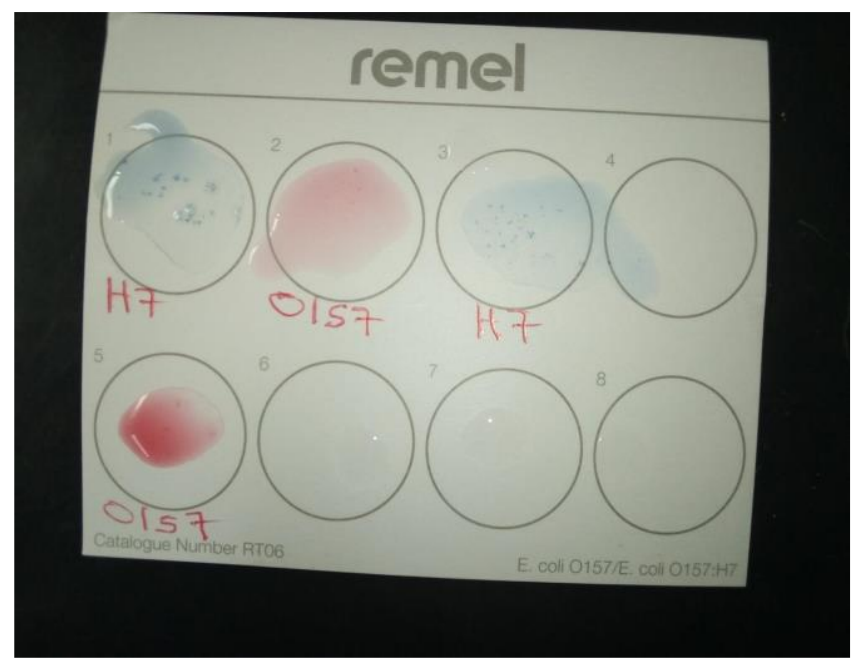

Plate 1 - Latex agglutination test for Escherichia coli 0157:H7

The confirmed Escherichia coli 0157:H7 was further subjected to a biofilm production assay to determine the phenotypic expression of colonies in the Congo Red Agar medium (Plate 2).

Briefly, the Congo Red Agar was prepared by dissolving $37 \mathrm{~g}$ Brain Heart Infusion agar (TITAN BIOTECH LTD), $36 \mathrm{~g}$ sucrose and $0.8 \mathrm{~g}$ congo red (BDH LTD) in 1 litre of distilled water. The solution was sterilized by autoclaving at $121^{\circ} \mathrm{C}$ for 15 min. After inoculation, the plates were incubated for $18 \mathrm{~h}$ at $37{ }^{\circ} \mathrm{C}$, where the biofilm-producing isolates originate as black colonies $[4,5]$.

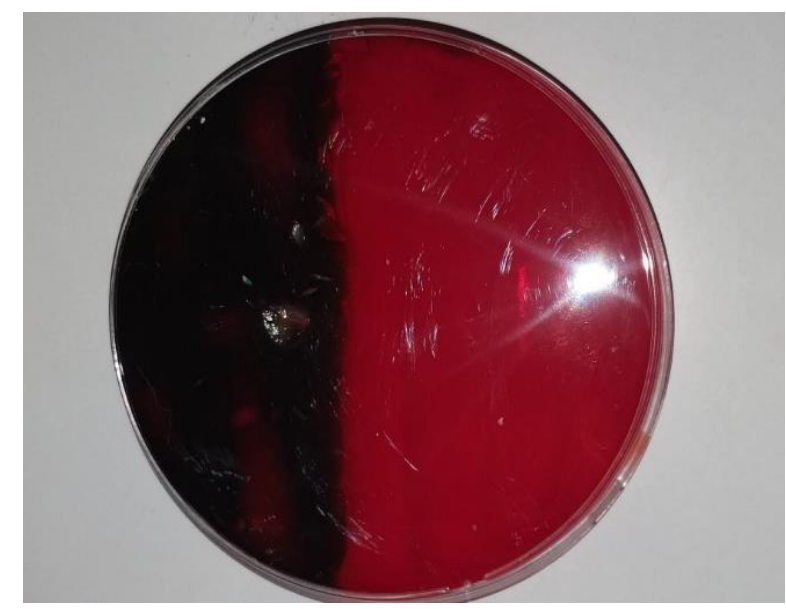

Plate 2 - Biofilm formation potential of Escherichia coli 0157:H7 congo red agar

The inocula of the potent biofilm-forming strains were prepared and subcultures on TSA, which was incubated at $37^{\circ} \mathrm{C}$ for $24 \mathrm{~h}$. Colonies of each isolate were then transferred into TSB using a sterile cotton swab to match the turbidity standard of $0.5 \mathrm{McF}$ arland $\left(15 \times 10^{8} \mathrm{CFU} / \mathrm{ml}\right)$.

The food additives (sodium citrate, sodium nitrite and cinnamic aldehyde) were purchased and prepared in solutions. The solution was then diluted to different concentrations based on the application amount for food preservation (2\%, $1 \%, 0.5 \%, 0.25 \%$ and $0.125 \%$ ) with an appropriate solvent [6].

In-vitro antimicrobial activity of food additives was conducted against isolated Escherichia coli 0157:H7, using the agar well diffusion method as described by the Clinical and Laboratory Standards Institute [6]. The standardized isolate was streaked over the entire surface of Mueller Hinton agar plates with a sterile cotton swab. Then, a hole with a diameter of 6 is punched aseptically with a sterile cork borer, and a volume of $100 \mu \mathrm{l}$ of different concentrations of food additives (Sodium citrate, Sodium nitrite, Cinnamic aldehyde) was introduced into the well, Augmentine disc $30 \mu \mathrm{g}$ (Oxoid) was used as a positive control in the assay. The plates were then incubated at $37^{\circ} \mathrm{C}$ for $24 \mathrm{~h}$. The size of the clear zone was measured in $\mathrm{mm}$. This assay was done in triplicates.

The recommendation of [6] performed the Minimum Inhibitory Concentrations and Minimal Bactericidal Concentrations determination. These were performed in a 96-well microtiter plate using a two-fold micro broth dilution technique using an inoculum that matched McFar- 
land's turbidity standard $\left(1.5 \times 10^{8} \mathrm{CFU} / \mathrm{ml}\right)$. The MIC is the lowest food additive concentration that completely inhibits visible growth. The MBC was determined by subculturing the wells onto the MHA plate that showed no visible increase for the MIC.

Time-kill kinetics assay of the solutions of the food additives was carried out following the procedure described by [7]. The keys were prepared for concentrations equal to $1 \mathrm{X}$ MIC, 2X MIC, and 4X MIC. An inoculum size of $1.0 \times 10^{8} \mathrm{CFU} / \mathrm{ml}$ was added and incubated at $37^{\circ} \mathrm{C}$. Aliquots of $1.0 \mathrm{ml}$ of the medium were taken at time intervals of 0 , $1,2,3,4,5,6,12$, and $24 \mathrm{~h}$ and were inoculated aseptically into $20 \mathrm{ml}$ nutrient agar and incubated at $37^{\circ} \mathrm{C}$ for $24 \mathrm{~h}$. A control test was performed for the organism without the additives. The colony-forming unit (CFU) of the microorganisms was determined. The procedure was performed in triplicate (three independent experiments), and a graph of the $\log \mathrm{CFU} / \mathrm{mд}$ was plotted against time.

The results were expressed as mean \pm SD twoway ANOVA test was used to compare results among and within groups for any significant dif- ference in efficacy of food additives against biofilm-forming Escherichia coli 0157:H7 using SPSS version $(\mathrm{P}<0.05)$.

\section{RESULTS AND DISCUSSION}

The isolate was confirmed to be Escherichia coli 0157:H7 due to the appearance of colourless colonies on sorbitol MacConkey agar and agglutination with a latex agglutination kit.

The isolate obtained was confirmed to be biofilm producer on congo red agar due to the formation of dark colonies on the media indicating slime production. Hence, Escherichia coli 0157:H7, which commonly contaminates food and contact surfaces in food industries, can develop a biofilm.

In vitro antimicrobial effects of food and preservatives have been elucidated as to the susceptibility or how resistant an organism is to it. In this study, the antimicrobial susceptibility pattern of sodium citrate, sodium nitrite and cinnamaldehyde showed (Table 1) a high zone of inhibition $(\mathrm{mm})$ of $13.00 \pm 0.88,26.00 \pm 0.58$ and $31.67 \pm 0.88$, respectively, at $2 \%$ concentration each.

Table 1 - Antimicrobial susceptibility pattern showing mean zone of growth inhibition $(\mathrm{mm}) \pm$ SEM of food additives against Escherichia coli 0157:H7

\begin{tabular}{|l|c|c|c|c|c|}
\hline \multirow{2}{*}{ Food additives } & \multicolumn{5}{|c|}{ Concentrations (mg/ml) } \\
\cline { 2 - 6 } & $2 \%$ & $1 \%$ & $0.5 \%$ & $0.25 \%$ & Control \\
\hline Sodium citrate & $13.00 \pm 1.15$ & $10.00 \pm 0.58$ & $9.00 \pm 0.58$ & $7.67 \pm 0.33$ & $24.6 \pm 0.85$ \\
\hline Sodium nitrite & $26.00 \pm 0.58$ & $20.33 \pm 0.88$ & $14.67 \pm 0.67$ & $10.33 \pm 0.88$ & $24.8 \pm 0.52$ \\
\hline Cinnamaldehyde & $31.67 \pm 0.88$ & $27.33 \pm 0.33$ & $25.33 \pm 0.33$ & $17.67 \pm 0.88$ & $25.6 \pm 0.89$ \\
\hline
\end{tabular}

Notes: Zones of growth inhibition = diameter of well plus zones of growth inhibition; diameter of well $=6 \mathrm{~mm}$. The mean growth inhibition zone was determined from three independent results $(n)=3$; SEM = standard error mean.

The most miniature zone of inhibition recorded for each additive was $0.25 \%$ concentration where sodium citrate had $7.67 \pm 0.33 \mathrm{~mm}$, sodium nitrite; $10.33 \pm 0.88 \mathrm{~mm}$ and cinnamaldehyde $17.67 \pm 0.88 \mathrm{~mm}$. Among the three additives used, cinnamaldehyde has the highest zone of inhibition $(31.67 \pm 0.88) \mathrm{mm}$. At the same time, sodium citrate showed the smallest area of inhibition $(7.67 \pm 0.33) \mathrm{mm}$ thus, showing that cinnamaldehyde has a strong antimicrobial effect against Escherichia coli 0157:H7. This finding is in line with the work of [8], who reported antimicrobial susceptibility of cinnamaldehyde against avian Escherichia coli inhibition zones diameters rang- ing from 16 to $44 \mathrm{~mm}$. Similarly, the report made by [9] on microbiological profiling of food additives and evaluation of their antibacterial efficacy showed a clear zone of inhibition of 8-22 mm measured on agar well diffusion.

The minimum inhibitory concentration (MIC) and minimum bactericidal concentration $(M B C)$ of sodium citrate, sodium nitrite and cinnamaldehyde recorded showed (Table 2) that all the three additives have varying MIC and MBC that can inhibit and cause a lethal effect on biofilmforming Escherichia coli 0157:H7. 
Table 2 - Minimum inhibitory concentration and minimum bactericidal concentration of food additives against Escherichia coli 0157:H7

\begin{tabular}{|c|c|c|c|c|c|c|c|c|}
\hline Food additives & \multicolumn{6}{|c|}{ Concentrations $(\mathrm{mg} / \mathrm{ml})$} & MIC & MBC \\
\hline \multirow[t]{2}{*}{ Sodium citrate } & 0 & 0.625 & 1.25 & 2.5 & 5 & 10 & \multirow{2}{*}{$2.5 \mathrm{mg} / \mathrm{ml}$} & \multirow{2}{*}{$5 \mathrm{mg} / \mathrm{ml}$} \\
\hline & + & + & + & - & - & - & & \\
\hline \multirow[t]{2}{*}{ Sodium nitrite } & 0 & 0.625 & 0.125 & 0.25 & 0.5 & 1 & \multirow{2}{*}{$0.25 \mathrm{mg} / \mathrm{ml}$} & \multirow{2}{*}{$1 \mathrm{mg} / \mathrm{ml}$} \\
\hline & + & + & + & - & - & - & & \\
\hline \multirow[t]{2}{*}{ Cinnamaldehyde } & 0 & 0.625 & 0.125 & 0.25 & 0.5 & 1 & \multirow{2}{*}{$0.125 \mu \mathrm{l} / \mathrm{ml}$} & \multirow{2}{*}{$0.25 \mu \mathrm{l} / \mathrm{m}$} \\
\hline & + & + & - & - & - & - & & \\
\hline
\end{tabular}

Notes: MIC - Minimum inhibitory concentration; MBC - Minimum bactericidal concentration; + growth activity (MIC/MBC decrease); - no growth (MIC/MBC increase).

The result showed that sodium citrate had MIC at $2.5 \mathrm{mg} / \mathrm{ml}$ and $\mathrm{MBC}$ at $5 \mathrm{mg} / \mathrm{ml}$, sodium nitrite had MIC at $0.25 \mathrm{mg} / \mathrm{ml}$ and MBC at $1 \mathrm{mg} / \mathrm{ml}$ while cinnamaldehyde had MIC at $0.125 \mu \mathrm{l} / \mathrm{ml}$ and $\mathrm{MBC}$ at $0.25 \mu \mathrm{l} / \mathrm{ml}$. Compared to the three additives, cinnamaldehyde had the most potent inhibition and lethal effect at a lower concentration than sodium nitrite next to cinnamaldehyde, followed by sodium citrate as the weak with higher concentration. The MIC and MBC value for sodium citrate increase twice the MIC and MBC value of sodium nitrite and cinnamaldehyde. Thus, cinnamaldehyde and sodium nitrite have strong bactericidal and bacteriostatic effects, while sodium nitrite has weak bacteriostatic and bactericidal effects. This finding agrees with the work of [5]. The MICs of sodium citrate and cinnamaldehyde against $S$. aureus at $5 \mathrm{mg} / \mathrm{ml}$ and $0.5 \mu \mathrm{l} / \mathrm{ml}$ and $\mathrm{MBC}$ at $40 \mathrm{mg} / \mathrm{ml}$ and $2 \mu \mathrm{l} / \mathrm{ml}$, respectively. The effect of cinnamaldehyde in fruit juice was reported to be at 0.25 to $1.5 \mu \mathrm{l} / \mathrm{mL}$ con- centration, which completely inhibited the growth of S. enterica and Escherichia coli 0157:H7 with MIC value of $0.25 \mu \mathrm{l} / \mathrm{ml}$ [10].

The time-kill kinetics profile of sodium citrate, sodium nitrite and cinnamaldehyde against Escherichia coli 0157:H7 showed (Figure 1-3) a varying pattern of reduction in the number of viable cells within $24 \mathrm{hrs}$ at different concentrations with a significant difference at $\mathrm{p}=0.05$ when compared to control (growth of organism without antimicrobial agents).

Time-kill kinetic profile of sodium citrate at $1 \mathrm{X}$ MIC showed (Figure 1) no reduction in some viable cells with steady growth from 2-4 hrs compared to the control. At 6-8 hrs, there was a reduction in the number of viable cells followed by a gradual rise from 10 up to $24 \mathrm{hrs}$. At $8 X$ MIC, a reduction in the number of viable cells was observed from 2 hrs of incubation with a gradual decrease in cell number up to $24 \mathrm{hrs}$.

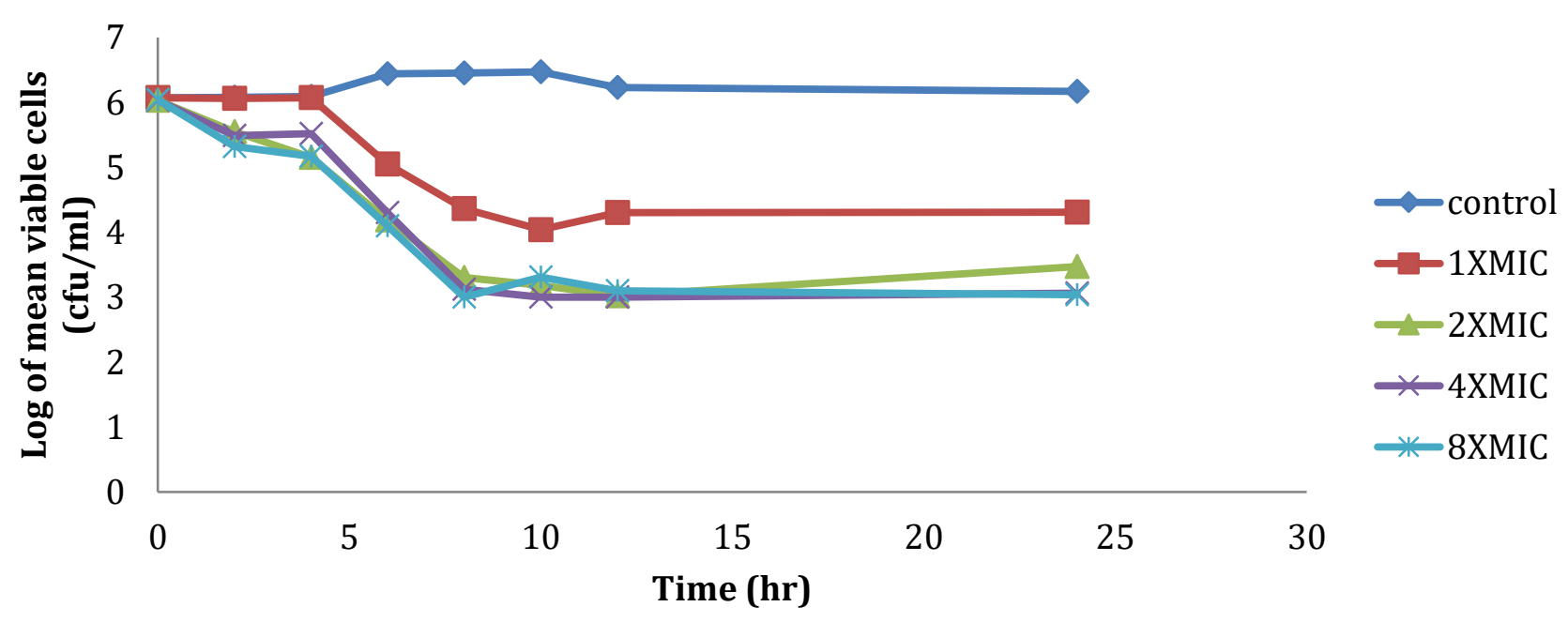

Figure 1 - Time-kill kinetic effect of sodium citrate against biofilm forming Escherichia coli 0157:H7 


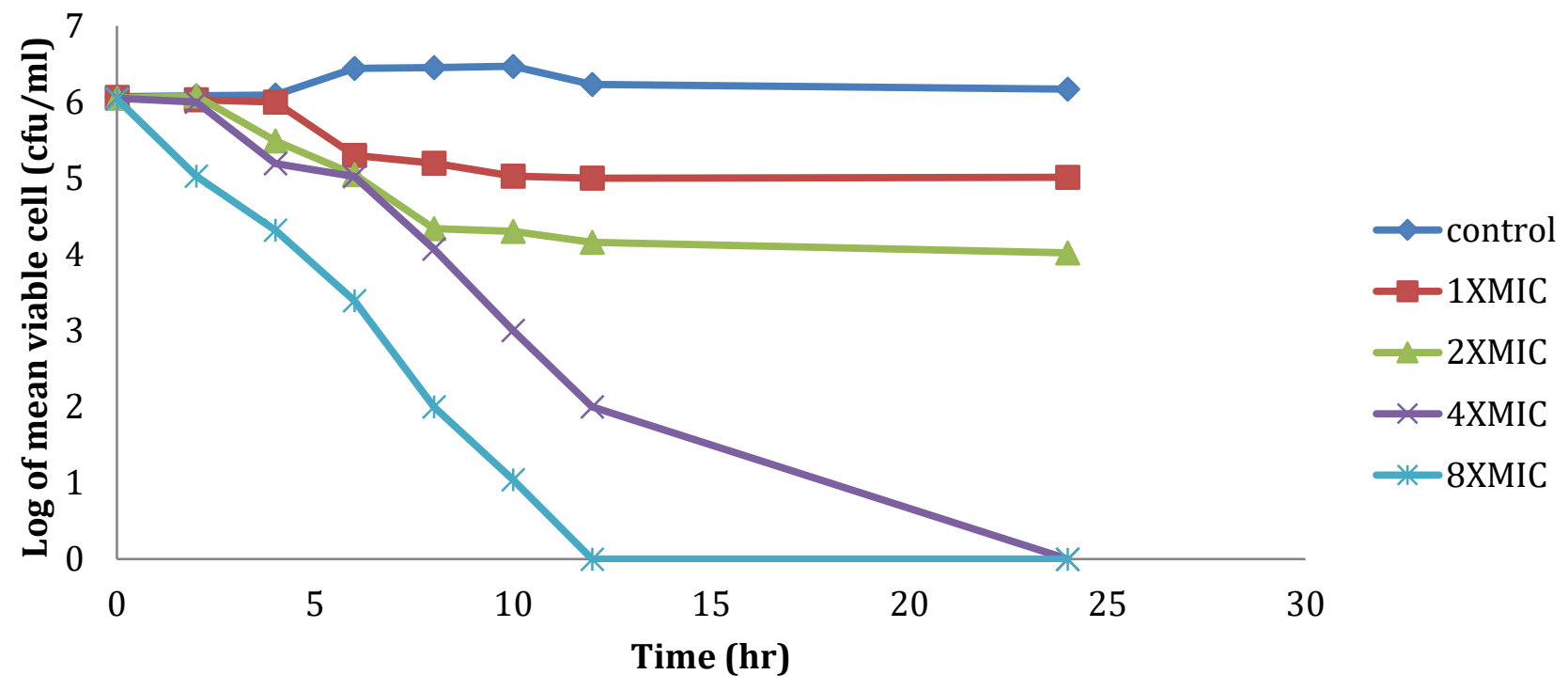

Figure 2 - Time-kill kinetic effect of sodium nitrite against biofilm-forming Escherichia coli 0157:H7

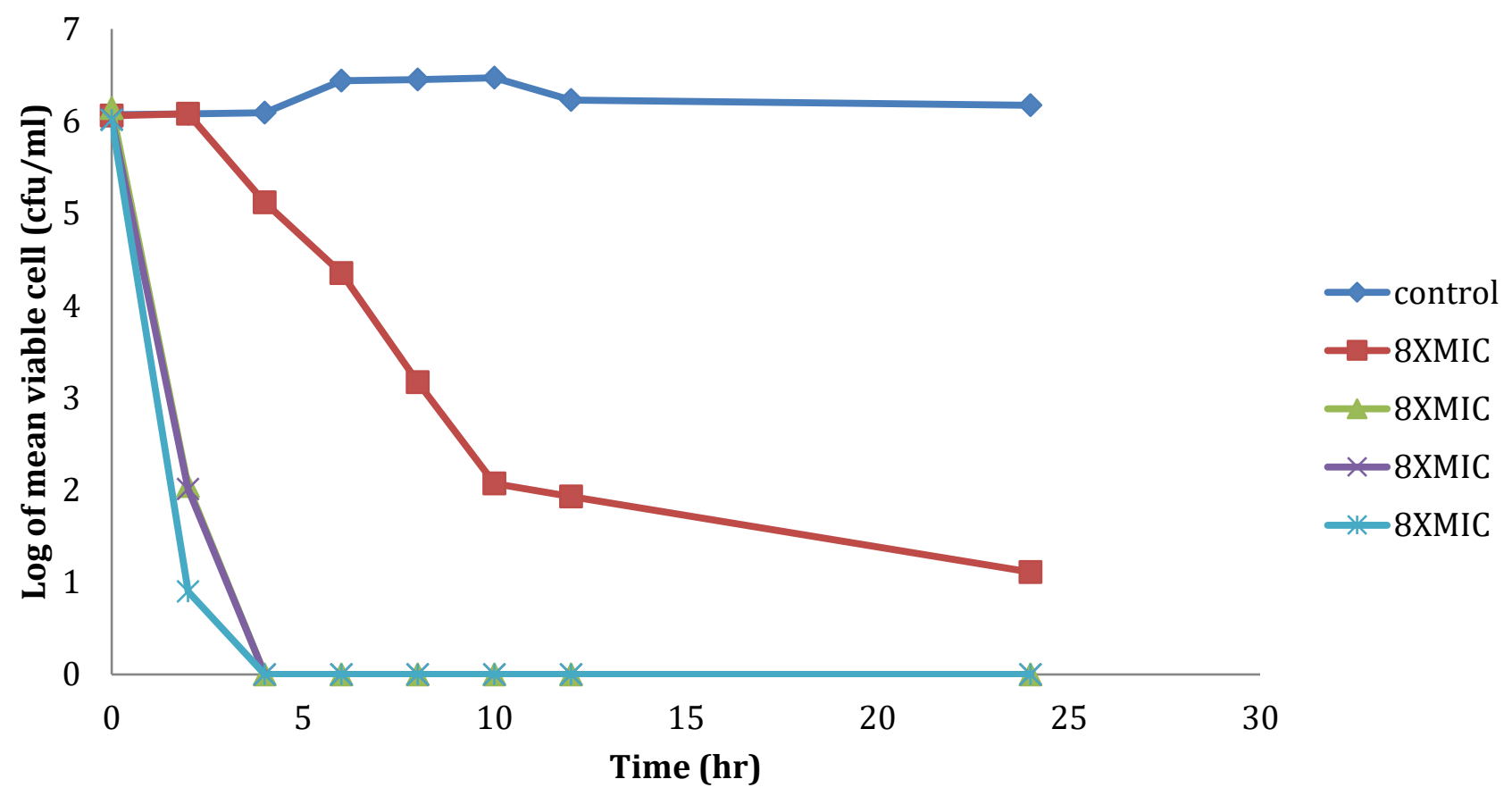

Figure 3 - Time-kill kinetic effect of cinnamaldehyde against biofilm-forming Escherichia coli 0157:H7

The time-kill kinetic profile of sodium nitrite at different test concentrations showed (Figure 2) a decline in the number of viable cells between 6$24 \mathrm{hr}$ at $1 \mathrm{X}$ MIC while reducing the number of the cell at the highest concentration used (8X MIC) was observed from $2-10 \mathrm{hrs}$. No growth was seen when subcultured and incubated between 12-24 hrs, thus making it bactericidal. Cinnamaldehyde showed (Figure 3) a more vital time-kill profile than sodium citrate and sodium nitrite by exhibiting bacteriostatic and bactericidal effects against the test isolate within $24 \mathrm{hrs}$ at varying tests concentrations. At $1 \mathrm{X}$ MIC, there was a gradual decrease in viable cell count. Complete inhibition of growth was observed between 4-24 hrs. This work agrees with [10] on the effect of cinnamaldehyde in fruit juice was reported to be at 0.25 to $1.5 \mu \mathrm{l} / \mathrm{ml}$ concentration, which completely inhibited the growth of $S$. enterica and Escherichia coli 0157:H7 with MIC value of $0.25 \mu \mathrm{l} / \mathrm{ml}$. 
Similarly, [8] reported a $99.9 \%$ reduction of Escherichia coli 0157:H7 at 8X MIC of cinnamaldehyde but slower in action. Bacterial sensitivity to certain antimicrobials may be partly attributed to the increased fluidity of the cytoplasmic membrane. Stringent control of membrane fluidity is crucial for membrane-associated functions such as active transport of solutes, passive permeability to hydrophobic molecules and protein-protein interactions. The cytoplasmic membrane is the primary cellular site where cinnamaldehyde exerts its antibacterial action; therefore, cinnamaldehyde, by exerting a membrane-fluidizing effect, may further disrupt those membrane-associated functions. Although the precise mechanism of antibacterial activity of cinnamaldehyde is inconclusive, it is believed that cinnamaldehyde inactivates bacteria by inhibiting ATPase at sub-lethal concentrations and disrupting the cytoplasmic membrane at lethal concentrations. The finding shows that sodium citrate, sodium nitrite, and cinnamaldehyde are bacteriostatic and bactericidal molecules.

\section{CONCLUSION}

The isolate was identified as Escherichia coli 0157:H7 through biochemical characterization and latex agglutination test. The antimicrobial susceptibility test revealed that the isolate is susceptible to the additives, showing cinnamalde- hyde stronger antimicrobial effect against Escherichia coli 0157:H7. The minimum inhibitory concentration of sodium citrate required to inhibit the growth of Escherichia coli 0157:H7 was obtained at $2.5 \mathrm{mg} / \mathrm{ml}$, sodium nitrite at 0.25 $\mathrm{mg} / \mathrm{ml}$ and cinnamaldehyde at $0.125 \mu \mathrm{l} / \mathrm{ml}$. the minimum bactericidal concentration was obtained at $5 \mathrm{mg} / \mathrm{ml}, 1 \mathrm{mg} / \mathrm{ml}$ and $0.25 \mu \mathrm{l} / \mathrm{ml} \mathrm{re-}$ spectively. Sodium citrate was found to be bacteriostatic between $6-8 \mathrm{hrs}$ with $72.9 \%$ reduction, sodium nitrite and cinnamaldehyde exhibit both bacteriostatic and bactericidal effects between 224 hrs with percentage inhibition of 65-90\% and 63-100\%, respectively. From this finding and comparative analysis, it is concluded that food additives (sodium citrate, sodium nitrite and cinnamaldehyde) can inhibit and can be used to control biofilm formation of E. coli 0257:H7.

\section{Acknowledgement}

Our profound gratitude goes to the supervisors and co-authors for dedicating so much time and energy in guiding, instructing and to colleagues that contributed in one way or the other toward the successful completion of the work.

\section{Conflict of Interests}

The authors declare no conflicting interest.

\section{REFERENCES}

1. Addis, M., \& Sisay, D. (2015). A review on major food borne bacterial illnesses. Journal of Tropical Diseases, 3(4), 1-7

2. Zhang, S., Wu, Q., Zhang, J., Lai, Z., \& Zhu, X. (2016). Prevalence, genetic diversity, and antibiotic resistance of enterotoxigenic Escherichia coli in retail ready-to-eat foods in China. Food Control, 68, 236-243. doi: 10.1016/j.foodcont.2016.03.051

3. Adamu, M. T., Shamsul, B. M. T., Desa, M. N., Khairani-Bejo, S., \& Irwan Syah, M. (2015). Assessment exposure to Escherichia coli among Halal cattle abattoir workers in Malaysia. Advances in Environmental Biology, 9(24), 204.

4. Oliveira, M., Bexiga, R., Nunes, S. F., Carneiro, C., Cavaco, L. M., Bernardo, F., \& Vilela, C. L. (2006). Biofilm-forming ability profiling of Staphylococcus aureus and Staphylococcus epidermidis mastitis isolates. Veterinary Microbiology, 118(1-2), 133-140. doi: 10.1016/j.vetmic.2006.07.008

5. Liu, L., Ye, C., Soteyome, T., Zhao, X., Xia, J., Xu, W., ... Harro, J. M. (2019). Inhibitory effects of two types of food additives on biofilm formation by foodborne pathogens. MicrobiologyOpen, 8(9). doi: $10.1002 / \mathrm{mbo} 3.853$

6. Clinical Laboratory Standards Institute. (2017). Performance Standards of Antimicrobial Susceptibility Testing (31st ed.). Retrieved from https://clsi.org/standards/products/microbiology/documents/m100/ 
7. Tsuji, B. T., Yang, J. C., Forrest, A., Kelchlin, P. A., \& Smith, P. F. (2008). In vitro pharmacodynamics of novel rifamycin ABI-0043 against Staphylococcus aureus. Journal of Antimicrobial Chemotherapy, 62(1), 156-160. doi: 10.1093/jac/dkn133

8. Khribch, J., Naima, S., Farida, L., Nassik, S., Zrira, S., El Houadfi, \& Oukessou, M. (2018). Antibacterial activity of cinnamon essential oil (cinnamomum cassia) and cinnamaldehyde on avian Escherichia coli strains. International Journal of Agriculture, Environment and Bioresearch, 3(4), 297-308.

9. Habiba, U., Rahman, M. M., Hossain, M. K., \& Nur, I. T. (2020). Microbiological profiling of food additives and evaluation of their antibacterial efficacy. Stamford Journal of Microbiology, 9(1), 23-26. doi: 10.3329/sjm.v9i1.45654

10. Manu, D.K. (2016). Antimicrobial Activity of Cinnamaldehyde or Geraniol alone or Combined with High Pressure Processing to Destroy Escherichia coli 0157:H7 and Salmonella enterica in Juices (Doctoral thesis). Retrieved from

https://dr.lib.iastate.edu/server/api/core/bitstreams/ea240f24-9808-4d51-98e56e323e57b1cf/content 